University of Wollongong

Research Online

Faculty of Social Sciences - Papers (Archive) Faculty of Arts, Social Sciences \& Humanities

2016

Musical Melanesianism: Imagining and Expressing Regional Identity and Solidarity in Popular Song and Video

Michael Webb

University of Sydney

Camellia B. Webb-Gannon

University of Wollongong, camellia@uow.edu.au

Follow this and additional works at: https://ro.uow.edu.au/sspapers

Part of the Education Commons, and the Social and Behavioral Sciences Commons

Research Online is the open access institutional repository for the University of Wollongong. For further information contact the UOW Library: research-pubs@uow.edu.au 


\title{
Musical Melanesianism: Imagining and Expressing Regional Identity and Solidarity in Popular Song and Video
}

\begin{abstract}
This article identifies and explores an emerging tendency among Melanesians to reenvision their region for the present time. It examines a corpus of popular songs and accompanying videos produced over the last decade that promote regional identity, a phenomenon driven by four factors: diasporic experience as well as a general increase in mobility and global awareness; dissatisfaction with the ruling class; desire to counter negative portrayals of the region abroad; and deep concern over the deprivation of fellow Melanesians' rights to political autonomy. The article demonstrates that this reenvisioning of Melanesianism reiterates key themes of the region's seminal postcolonial thinkers, Epeli Hau'ofa, Walter Lini, Bernard Narokobi, and Jean-Marie Tjibaou; at the same time it develops the concept of wantok-ism and elaborates the idea of "one skin" or blackness as distinctive, thus turning the pejorative associations and experiences of being labeled the black "nesia" into a feature to celebrate. Analysis in the article is guided by a framework that considers the lyrical, musical, and visual devices through which musical Melanesianism is being articulated and projected: mapping, flagging, dancing, and vocality-devices from the "do-it-yourself kit" for performing regionalism.
\end{abstract}

\section{Keywords}

video, song, musical, popular, solidarity, identity, regional, expressing, imagining, melanesianism:

\section{Disciplines}

Education | Social and Behavioral Sciences

\section{Publication Details}

Webb, M. \& Webb-Gannon, C. (2016). Musical Melanesianism: Imagining and Expressing Regional Identity and Solidarity in Popular Song and Video. Contemporary Pacific, 28 (1), 59-95. 


\section{Musical Melanesianism: Imagining and \\ Expressing Regional Identity and \\ Solidarity in Popular Song and Video}

\section{Michael Webb and Camellia Webb-Gannon}

From different cultures we may come speaking in different tongues, yet deep within, our souls touch each other through the language of music. With music we communicate and talk with a common language-with "one talk. Throughout Melanesia."

-Soru Anthony Subam ${ }^{1}$

Proclaimed as "a new anthem for all Melanesian people everywhere," the party pop song "Melanesia" (JJY)2 was launched in 20I I via iTunes and YouTube. ${ }^{3}$ Its opening lyrics trace the following cartography, delivered by multilayered Auto-Tuned vocals over a strong dance club beat:

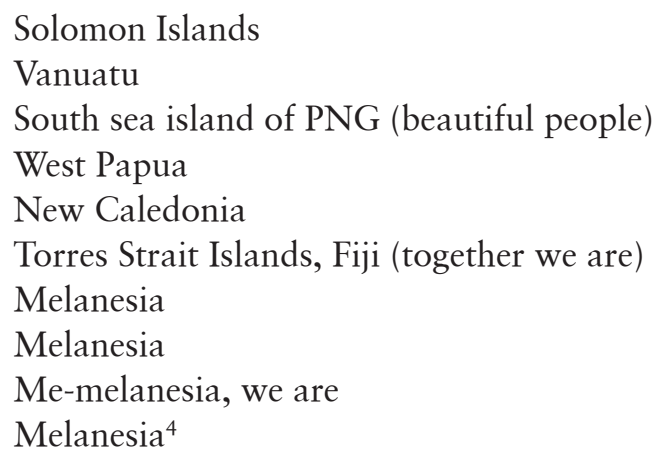

In the rap that follows, Melanesia is represented idyllically. Its text essentializes the region as an egalitarian island paradise of cool island breezes, swaying palm trees, and swinging hammocks, where beautiful

The Contemporary Pacific, Volume 28, Number I, 59-95

(C) 2016 by University of Hawai' $i$ Press 
girls with Afros shake their hips as they dance the hula. Melanesia is a region imbued with "Mela magic," where food "fresh from the garden" is available at the local market and the lifestyle is so casual that Islanders are "local tourists" ${ }^{5}$ who are "keepin' it real and simple." It would be easy to dismiss such sentiments as facile and overly nostalgic; however, delivered in this musical form, they encapsulate the anxieties many Melanesians experience today, whether "grassroots" or middle class. As Alex Golub explained, villagers "seek[ing] development, wealth, and modernity are excoriated by urbanites for betraying the [region's] deepest values," and urbanites "feel that their desire for modernity must be a sign of their deculturation" (2014, I62). The rap phrases "lovin' my people, keepin' the culture alive," "fantastic just the way we were made," and "welcome to my side of the world" indicate that the song articulates an attempt to resolve this sense of conflict between modernity and tradition.

"Melanesia" (JJY) originates from a small but growing diasporic community of Melanesians based in Brisbane, Australia. Jagarizzar (Renagi $\mathrm{Va}^{\mathrm{c}} \mathrm{a}$ ) and J-Lee (Jamie Lee) of Papua New Guinea (PNG) and Yung Yanny of Solomon Islands wrote the song. The recording was produced by Papua New Guinean Bradley "B-Rad" Ralewa for the Tuff Tumas label, which is operated by a ni-Vanuatu producer of European descent. "Melanesia" (JJY) is one of an increasing number of songs from this southwestern corner of the Pacific Islands in recent years that indicate a desire on the part of many Melanesians to reenvision their region for the present time.

Taking cues from a range of such popular songs released between 2004 and 20I4-with the notable precursors Rootstrata's "Brother Kanaki" and Jale Mareau's "Melanesia," which from various perspectives promote Melanesian identity-in this article we propose that such a phenomenon is driven by four factors that are equal in significance. First, Melanesians are becoming ever more mobile and globally aware and understand themselves individually and collectively in new ways. Increased access to social media and technology forms has provided them with a voice, and they are keen to express these notions to each other. Second, the musical reenvisioning arises from but also contributes to an emerging Melanesian geocultural politics that relates to the current demographic and political realities of the region: "large, youthful populations that are tired of the status quo and leaders who have failed to manage change, including generational change of political leadership" (PIPP 2OII). Third, the reenvisioning is in part a response to negative perceptions of the region circulating in the international media that, again, is addressed not to outsiders but rather to 
Melanesians. Fourth, based on affinities of ethnicity and geography, and employing a unique, local politics of blackness grounded in the region's historical labeling as the "black" and, by inference, inferior islands, it affirms solidarity with demands for political independence, in particular in West Papua. ${ }^{6}$ This is conveyed through music, dance, and video productions that voice a Melanesia-wide opposition to ongoing settler colonialism in the occupied Melanesian territories. Such expressions have been less vocal regarding New Caledonia's occupation by France than West Papua's by Indonesia, perhaps because of the international legal accord providing for a referendum on independence for New Caledonia within the next three years and also the comparatively scant international legal attention paid to West Papuans' plight.

"The body in Melanesia," Bruce Knauft explained, "is a performative that binds people together in intricate webs of meaning and experience" (I999, 84). Julian Smythe provided an example, arguing that in West Papua, song is a "participative symbol that renegotiates boundaries of Papuan identity" previously defined under Dutch and Indonesian colonialism (2013, 74). In West Papua, particular sung repertoires create and maintain "the daily liberational practice of sustaining the ideological 'Notion-State' of Papua" (Smythe 20I3, 74). Echoing and expanding geographically on Smythe, we propose that songs, singing, and music and dance performances, which increasingly are being circulated and consumed in video form, are becoming crucial sites in the ongoing construction of "Melanesian-ness" and projection of "Melanesianism."

More broadly, we intend to contribute to Stephanie Lawson's recent discussion of the "Melanesian enterprise" of the "construction of a positive Melanesian identity" (20I3, I 8 ) by examining aspects of current expressive practices through which "the meaning of Melanesia [is brought] under the control of those to whom it applies" (Lawson 2013, 22). As will be seen, performed Melanesian-ness is liberational in Smythe's sense in that it voices solidarity with West Papua in the fight against Indonesian domination and, as already noted, to a lesser extent with Kanaky or New Caledonia against French colonization. Musical Melanesianism is also liberational in ways Lawson outlined, through its expression of deep pride in and "ontological attachment to the idea of Melanesia as a legitimate and very real geocultural space with certain distinctive attributes" (Lawson 2013, 22).

Constructions of Melanesian-ness, as Lawson explained, work in opposition to or in contrast with not only "the West" but also Polynesia, and, 
we contend, Asia. The "song map" presented in "Melanesia" (JJY) systematically delineates the region of Melanesia by "pushing back" current political borders: it declares that West Papua is part of Melanesia and not Asia; that the Torres Strait Islands are part of Melanesia, not Australia; and that Fiji is part of Melanesia, not Polynesia. Obliquely the lyrics also refer to "South Sea Islanders," Australia's "other" Melanesians, the descendants of those involved in the nineteenth-century Pacific Islands disreputable labor trade. Hence, in marking out a space on the world map by emphasizing that the region is bounded by Others-Asian (Indonesia), "European" (Australia), as well as Islander (Polynesia) - the song symbolically rescues Melanesia from global liminality. As will be seen from the corpus of songs we discuss, understandings and representations of Melanesian-ness are also nested; that is, the region is understood from a very specific local and (or) national point of view.

Further, through music - lyrics as well as style—notions of blackness are evoked in the service of Melanesian identity. Appropriating and absorbing musical styles such as reggae and hip-hop allow some Melanesians to identify with a wider black transnation, an idea explored further below. It should be noted, however, that in Melanesian reggae, ideas of blackness and senses of "island easygoing-ness" often intersect or merge. These qualities no doubt stem from what David Henderson referred to as reggae's "dialectic of ebullience and indignation," although in some Melanesian forms of reggae, the dialectic can be breached or at least culturally filtered (2OI4). ${ }^{7}$

The fact that it is a musical Melanesian-ness and Melanesianism under discussion poses a challenge, we believe, to Lawson's conclusion that "the salience of the idea of Melanesia [underpins] the identity of the region's elites more so than those at the grassroots level" (2013, 22). Popular music possesses the potential to disseminate ideas quite broadly, ideas that can be sung and danced into dispositions, values, and beliefs. As Robert Foster wrote, "pop songs played on commercial FM stations" in Papua New Guinea are among the key mass-mediated means by which "the nation materializes both as an unnoticed banality and as an object of explicit interest and contest" $(2002$, I 2$)$. Increasingly it appears that the Internetvia Facebook, YouTube, SoundCloud, blog sites, and so on-is playing a similar role in circulating understandings of the Melanesian region. This is music that in the main is produced not by musicians at the grassroots level, but rather by those operating from within an urban-based middle tier, who are increasingly gaining access to home-recording technology. 


\section{Melanesian Consciousness and Musical "WANTOK-ISM"}

Lawson traced the historical and anthropological "construction of Melanesia," as well as the foundations and subsequent transformation of the concept of "Pacific Way," before discussing the various "discourses promoting a positive Melanesian consciousness within individual Melanesian countries as well as in the broader region" $(2013,17)$. These began to emerge in the early decolonization years of the I970s and include the various codifications of a Melanesian Way or a set of values put forward by leading intellectuals-Bernard Narokobi in Papua New Guinea, JeanMarie Tjibaou in New Caledonia, Walter Lini in Vanuatu, and Epeli Hau'ofa (who was born and worked in Melanesia)—as well as regional understandings of kastom or tradition that became a focus of anthropological interest in the r980s. Positive Melanesian consciousness, Lawson noted, was "further strengthened by the celebration of Melanesian identity as manifest in the Melanesian Arts Festival, initiated by the [Melanesian Spearhead Group] in I995" (2013, I 8).8

The Melanesian concept of "wantok" - a pidgin term derived from the English words "one" and "talk," used to express "solidarity with kin" (Golub 20I4, I74)-is a key factor in the shaping of regional identity, as Lawson made clear. It has been developed and applied to members of communities from the very local to the national and regional levels, "indicating at once both the actual diversity of Melanesia as well as its conceptual unity in contradistinction to both Polynesia and Micronesia" (Lawson 2013, I8). In the statement that appears at the opening of this article, by way of the pun "one talk," the influential Papua New Guinean musician Tony Subam declared that, in the face of the region's profound linguistic diversity, music is its binding communicative medium. For Subam, and increasingly for other musicians, Melanesians' wantok bonds are maintained and strengthened through music, the "one talk." This idea bears closer examination.

According to Clive Moore, in Melanesia there is an "invisible strength that unites the diverse ethno-linguistic groups," and that is the "interlocking exchange systems and associated human interchanges" (2003, xi). Anthropologist Simon Harrison has argued that Melanesian societies have been understood as being "culturally highly acquisitive," displaying "a highly developed propensity to borrow one another's traits" (I993, 39, I42). This has been evident particularly in the ways rituals and their components- 
including songs, instruments, and dances-were traded and hence disseminated. Relatedly, many scholars have noted Melanesian societies' particular receptivity to novel cultural items. Regardless of whether the language of the texts of songs was understood, songs and dances circulated well beyond their place and culture of origin, which goes toward explaining, perhaps, why Peter Crowe asserted that, "despite its astonishing variety, there seems to be a Melanesian traditional music 'sound,' directly recognisable to anyone who has heard enough, but eluding description” (I995, I47).

In early post-contact times, Melanesians demonstrated a willingness to embrace music from outside their region, a notable case being Protestant hymnody (see Webb 2015). Following its introduction in the mid-nineteenth century, Islanders became adept hymn singers; by the time of the Pacific War, hymns had become a lingua franca of sorts (Barker I992, I 58 ; Lindstrom and White I990, I65). Well before the turn of the twentieth century, "Pacific" songs began to travel along shipping lanes to Melanesian ports (see Carr 20I4), and some of these songs eventually found their way to plantations and goldfields-wherever labor opportunities beckoned. String band emerged after the war as a local version of hillbilly or bluegrass and other American old-time music forms, then variants of country and rock 'n' roll became popular with the establishment of radio. By the mid-200os, the sounds of reggae, $R \& B$ (contemporary rhythm and blues), and hip-hop had saturated the Islands. With the aid of the local music industry, these styles have shaped popular music for more than a generation of Melanesian consumers. Each new music type brought its own aural-symbolic representations of space and place, which, through complex and varying processes, were reconfigured on local politico-aesthetic terms (Cattermole 2009). Crowe's remarks concerning a Melanesian traditional music sound apply equally to post-contact music forms. Subam probably had music in general in mind rather than a singular Melanesian sound when he proposed the idea of "one talk"; music, however, has been used in broadening the applicability of the concept of wantok.

The poster reproduced in figure I provides an example of how more recently musical style and the wantok concept have intersected. It advertises a concert held in Brisbane in July 20I I; the red, green, and yellow colors of what is known as the Rastafarian or reggae flag spell out the wantok theme, linking the concert's title with the national origins of participating Melanesian performers: red for Solomon Islands, green for Vanuatu, and so on. This constitutes a particularly interesting instance of the "flagging" device discussed below. The combination of red, yellow, 


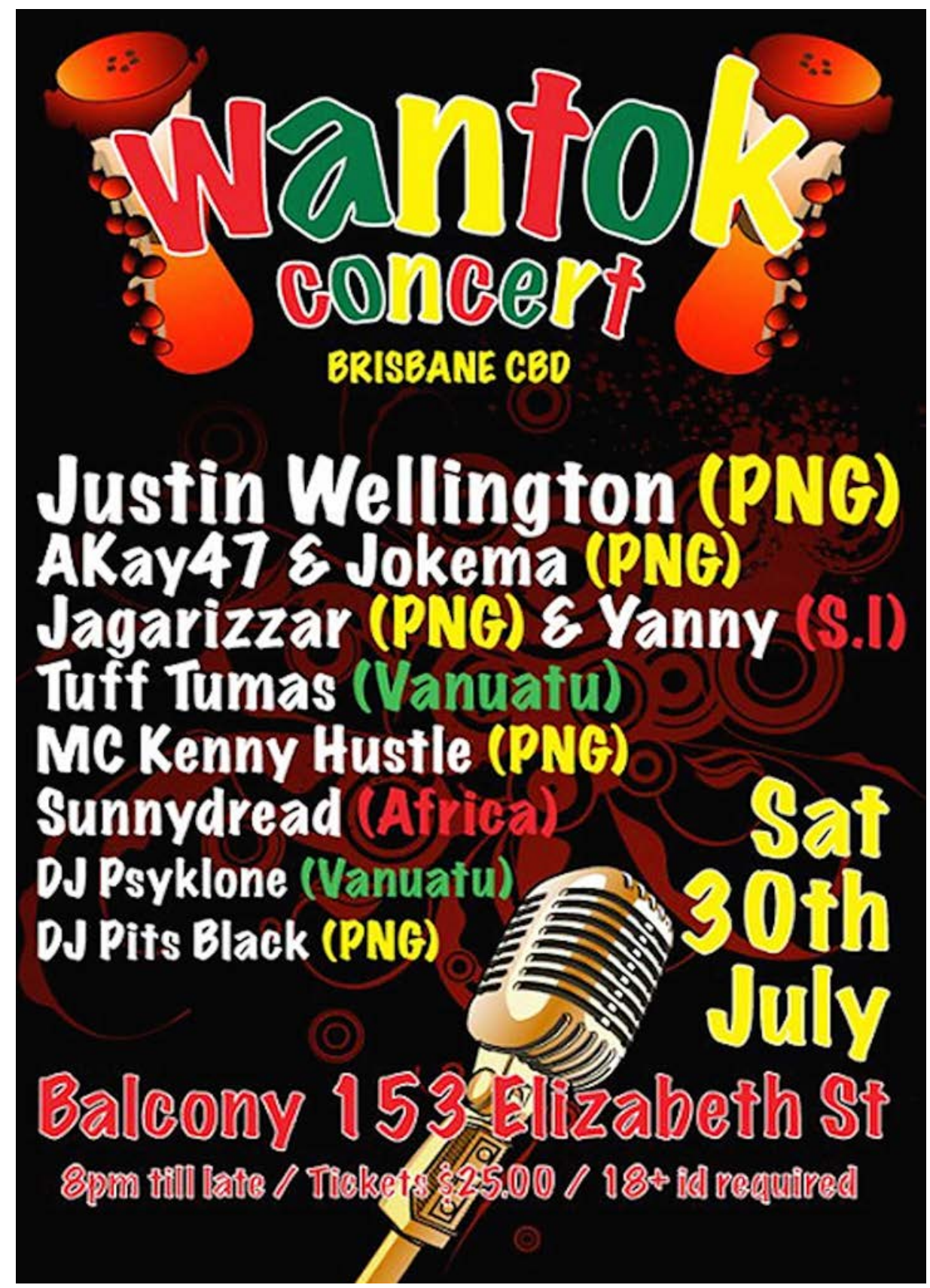

Figure I Poster indicating the musical projection of Melanesian wantok-ism: Reggae wantok concert, Brisbane, 30 July 20 I I. 
and green was adopted from the Ethiopian flag by many African nations and pan-African organizations, as well as by adherents of Rastafarianism in Jamaica, through which it is closely linked with reggae music. In this instance, by way of the shared music form of reggae, and given that Sunnydread from "Africa" was also on the concert roster, the Rastafarian colors signal both inchoate notions of "black wantok" and the idea of a black transnation (which will also be taken up below). A gleaming microphone, symbolizing contemporary live performance and the broadcasting of Melanesian voices in one of Australia's major urban centers, is prominent in the lower foreground, and a pair of kundu traditional hourglass drums, from Papua New Guinea but symbolizing Melanesian customary performance, stand behind the concert title as if to emphasize the Melanesian-ness of the concept. The message is clear: music, especially reggae music, unites wantoks but also facilitates solidarity between Melanesians and black peoples more widely.

\section{Melanesians and Black Musical Identity}

Resonances of blackness began to be conveyed in local music in Melanesia in the I970s with the rise in popularity of a rock band comprised of West Papuans. Energized by the expressions of cultural pride and radical politics of the Black Power Movement, these musicians-who went on to become committed independence activists—-pointedly called themselves the Black Brothers. The Black Brothers name also picked up on nascent Melanesian senses of black pride, emphasizing in particular that the musicians and their fellow West Papuans are clearly un-Asian, in appearance and otherwise. Protesting Indonesia's colonization of West Papua, the Black Brothers announced their Melanesian identity through a spectacular yet apparently short-lived musical model for putting Melanesia "on the map," wherein traditional songs were fused with the musical devices and instrumentation of rock. ${ }^{9}$ As a single example of this model, their mid-to-late I970s track "Huembello" ${ }^{10}$ surely drew inspiration from the Afro-Latin musical tribalism of rock band Santana's "Jingo," which was a reworking of the popular song "Jin-go-lo-ba" by Nigerian percussionist Babatunde Olatunji-a musician who contributed significantly to an emerging sense of pride in African culture among African Americans in the early I960s (Charry 2005, I-2). The "tribal chant" of "Huembello" was a traditional song from the Ayamaru linguistic-culture area of the Bird's Head or Doberai Peninsula of West Papua, the home area of one of the 
band members. The song's virtual environment comprises a jungle menagerie assemblage of vocal screams, calls, whistles, and chatter, all enhanced with studio reverb, within which a Melanesian folk song bounces over a Latin funk jam groove interspersed with blues-rock riffs and solos, and which concludes with a percussion breakdown and fade-out. Contemporary musical expressions of regionalism must be traced back to the Black Brothers, who, having resided not only in West Papua but also for a time in Papua New Guinea and Vanuatu, are often credited with introducing reggae to Melanesia.

The idea of "Brother" accumulated multiple resonances in Melanesia. In the early Melanesian reggae song "Brother Kanaki," it serves as a synonym for wantok and conveys black solidarity in anticolonial struggle. Composed by Freddy Fesaitu of the Fijian band Rootstrata, which formed in I984, "Brother Kanaki" was probably the earliest overt musical expression of solidarity between Melanesian people groups and was prompted by the Kanak insurrection of 1984 and the events of its aftermath years concluding with the assassination in 1989 of Jean-Marie Tjibaou (Lyons I986, I29-I33; Waddell 2008, I36-I44). ${ }^{11}$ The text of the third verse and chorus conveys the intent of the song: ${ }^{12}$

\author{
Brother Kanaki don't feel you're alone \\ Every time you fall I'll sing this song \\ Together we'll sing the songs of your islands \\ Telling the world we're people of Jah Rastaman \\ Brother Kanaki \\ Brother Kanaki [etc]
}

Rootstrata's vision is articulated not as one of Melanesia as a region of independently governed countries but rather of a Rastafarian or black transnation. Hearing in a song the name "Kanaki," a variation on the word "kanaka," was particularly poignant due to its proud reclamation from a history in Melanesia of degrading connotations under colonialism. In Melanesian hip-hop contexts, kanaka is sometimes abbreviated to "naka" to convey solidarity or affection, similar to the way "nigga" has been used non-pejoratively in African American hip-hop (one PNG rapper, for example, performs under the name Naka Blood).

The musical exploration of identity politics elsewhere in the Pacific Islands also forms a backdrop to this discussion. Some Melanesian musicians have been encouraged in their endeavors by tracks such as "Paradise 
Lost," released in 1995 by the Hawaiian rap group Sudden Rush. ${ }^{13}$ At one point, the song's extended rap refers to a "true Aloha spirit," which recalls the notions of Pacific Way and Melanesian Way, and it denounces the loss and despoliation of indigenous land that resulted from outsiders imposing their interests on Islanders through the lyrical symbols gold, queen, and cross:

And there's no feeling like the feeling of the true Aloha spirit

Some people choose to fear it and some people wanna hear it

As plain as the gold on the solid gold chalice

As plain as the queen committed at the royal palace

As plain as the blood that was shed on the cross

We don't wanna live in a paradise lost

Significantly, Sudden Rush maintains a Hawaiian accent, or at least mostly avoids using a United States rap drawl, and includes Hawaiian-language phrases in their lyrical text.

George Veikoso, a Hawai'i-based Fijian singer who performs under the name "Fiji," is another influential source. Veikoso's anticolonial song "Warrior" (available on iTunes), from his 2008 album, Indigenous Life-which must owe a debt of inspiration to Bob Marley's I979 song of pan-African solidarity, "Africa Unite"-opens with an allusion to Martin Luther King Jr's famous 1963 "I Have a Dream" speech: "Well I have a dream to see the unification of Pasifikans." ${ }^{14}$ Veikoso adopts a kind of Jamaican patois accent and grammatical nuances as he sings:

This is a call for the unity of Polynesians, Micronesians and Melanesians

Return to your roots again

Never get caught up in all the political situations

That never gonna ever change

All they will do is try for trick us into another system

Remember where you are come from

It's way more complicated than you ever thought it was

O-oh-eh o-wo-wo-wo-wo-wo

I gotta remember my Chamorro people and Chuukese

Even Saipanese and Philippines (oo-ah)

I gotta remember the Gilbertese and all the Marshallese

You know I never forget you (no way)

Even my New Hebrides and my Papua New Guinea (my warriors)

I never forget you

Vanuatu all my wantok in Melanesian crew (woh-woh-woh)

I never forget you 
Kanaka maoli, tangata maori, ta'ata ma'ohi

Whatever you want to be known as

Just know that we are one in this Pasifikan land

Let us come together wo-wo-oh

These two brief examples provide an indication of how, as black musical transcultures, hip-hop and reggae well serve Islanders' political, cultural, and social concerns. The Melanesian songs we now examine find resonances in the way Veikoso maps out regions, and their singers gain confidence from his reference to the wantok concept as well as his call to know one's origin. However, given the recent accumulation of sung expressions of Melanesianism and Melanesian-ness, in the region there appears to be some resistance to such totalizing proposals as Veikoso's "Pasifikan land," and songs promoting Melanesianism are, on the whole, less strident in tone than these kinds of musical expressions of Pacific Islands identity.

We consider first a set of six songs, grouped in pairs, that probe aspects of Melanesian regional identity, and then examine an additional four songs advocating Melanesian support for West Papuan political independence. In these songs, "mapping" is a key lyrical device, while "flagging" and dancing are prominent visual devices. As Daniel Smail has shown, maps are "instruments and reflections of power" (1999, 3). In the lyrics under discussion, they represent a proclamation of territorial control, or a claim to ownership and a desire to reclaim such control. Indeed, in the song "Melanesia" (Jam) analyzed below, the rapper Jamala imagines "taking over territory like a tropical hurricane." Lyrical mapping takes one of two forms: either a listing of place-names, usually countries but sometimes regions, or a "from-to" contrasting, citing either cities or landscape features that are widely separated.

Flagging involves the appearance in the video visual frame of the various national flags of Melanesian countries or nations; juxtaposed, these "flag" the region (Foster 2002, II). ${ }^{15}$ Importantly, songs such as those under discussion are uploaded to YouTube, often with an accompanying listener-contributed slide sequence in which flags are a dominant visual theme. Sometimes alternate versions of such slide shows are shared in this way. In videos accompanying songs supportive of West Papuan political independence, the yospan "national" dance of West Papua is performed.

It is more difficult to identify specific devices of music sound as such; however, rapping-or its reggae form, toasting-is one that allows for brief or extended verbal expounding on facets of Melanesianism and 
Melanesian-ness. In songs espousing Melanesian identity, the way the voice is used is important. In her study of "rap vocality" and identity construction, Alyssa Woods identified "three aspects of vocal emphasis: accent [musical and linguistic], diction, and declamation" as carriers of important cultural information about, for example, "the rapper's geographical, ethnic, and class background" $(2009,23)$. We touch briefly on these aspects in our analyses.

\section{Melanesia in Song}

\section{Perspectives from Papua New Guinea}

The first pair of songs under discussion is "Papa Pacifica" (available on iTunes) and "Melanesia (Paradise)" (available on iTunes, where it is mistitled "Melanesian") by the Papua New Guinean pop band Hausboi, from their 2004 album Diriman (Tok Pisin: Dreams). There is an obvious connection between these and another pair, "Wan Nesia" and "Melanesia" (JJY) (referred to at the outset) from the 20 I I collaborative album Melanesia by Jagarizzar, J-Lee, and Yung Yanny (JJY). While it is not possible to undertake a detailed comparison of these two couplings, the following broad points should be noted: Hausboi's songs are largely in Tok Pisin (PNG English-based pidgin) and JJY's are in English; thus it can be assumed that the former band sings to a predominantly Papua New Guinean audience. Also, Hausboi's lyrics are more serious in intent; in a bouncy pop-reggae style, they encourage Melanesians to think positively about Melanesia. The JJY songs express pride in place and people but concentrate more on Islanders coming together to have a good time. Hausboi cheekily adopts as a band name the colonial word in Tok Pisin for domestic servant, while Jagarizzar, J-Lee, and Yung Yanny use catchy hip-hop-like monikers. The fact that "Wan Nesia" and "Melanesia" (JJY) are paired-one celebrating a broad-based Pacific identity, the other a Melanesian regional identity-indicates a tension that Islanders experience when they mix in urban situations in diaspora: on the one hand, they seek a broader sense of belonging; on the other, they strive to maintain their ethnic distinctiveness.

The title "Papa Pacifica" is notable for two reasons: first, its use of the term "Pacifica" and, second, the Tok Pisin pun on the word for father, used here to mean source or origin. The term "Pasifika" originated in New Zealand to designate both a group of people and an aesthetic style. According to Sharon Kornelly, the classification "Pasifika peoples" came 
into use "to preserve distinctions among Pacific Island groups while simultaneously removing boundaries and creating stronger alliances between them" (2008, 4I-42; see also McGavin 20I4, I34). As a kind of challenge to such a notion, Hausboi's song celebrates the populating of the Pacific Islands from west to east by the Lapita people, a "seafaring, technologyproducing Melanesian people with partial ancestors from the Austronesian migrations" (Matsuda 20I2, I7), and thus claims Melanesia as the place of source of all Pacific people groups:

\author{
Melanesia em i papa bilong Pasifika \\ Melanesia mi ya mi papa bilong Pasifika \\ (Melanesia is the source of all Pacific people \\ Melanesia I am the source of all Pacific people) \\ Long taim bipo ol i sel i kam long Melanesia \\ $\mathrm{Na}$ ol i kamapim papa bilong Pasifika \\ Ol tumbuna stori bilong ol Pasifika \\ Ol $i$ tok olsem ol $i$ kamap long ol Melanesia \\ (In the past they sailed to Melanesia \\ And they became the source of all Pacific people \\ The legends told by the Pacific people \\ Say that they all originated from Melanesians) \\ I stap we? I stap we? Papa Pasifika i stap we? \\ I stap hia I stap ya Papa Pasifika i stap ya \\ (Where is it? Where is it? Where is the source of all Pacific people? \\ It is here, here; Pacific people's source is here) \\ Long dispela taim yumi wanpela Pasifika \\ $\mathrm{Na}$ ol pasin na ol kalsa kamap long wanpela papa \\ (These days we are one Pacific people \\ All our customs and cultures came from a single source) ${ }^{16}$
}

John Faunt of Hausboi recalled that he was motivated to write the song after reading about "the origins of the Maori people." ${ }^{17} \mathrm{He}$ was intrigued to learn of a legend that claimed the first man to arrive in New Zealand was called "Kupe, which is a Manus name"; this caused him to wonder, "Could it be that the Melanesians that were picked up along the way were from Manus?" (pers comm, Faunt to M Webb, I7 Sept 20I4). Faunt, whose father is from Manus Province in Papua New Guinea, found appealing the idea that his own place was potentially a significant Pacific Islands origin site. 
The song's summary point, that "we are one Pacific people" because we come from a single source or place of origin, is also a fact that distinguishes Melanesia from the rest of the Pacific Islands; by inference, the song celebrates this point of distinction. The intent of "Papa Pacifica" is clarified and perhaps amplified by its proximity on the album and its musical similarities to a second song: "Melanesia (Paradise)." Both songs employ a reggae-pop style base, although "Melanesia (Paradise)" features a slower, more relaxed tempo and a double-time strummed ukulele rhythm that fills in the space created around the electric guitar skanking pattern; the sound of MIDI steel drums and Jamaican Patois accent evoke the Caribbean. In "Papa Pacifica," the Patois accent is even more pronounced, although in both songs it is offset with the use of Tok Pisin, one of Melanesia's multiple pidgin languages. The refrains of each-"Melanesia em i papa bilong Pasifika" and "My Melanesia waiting to please ya," respectively-are melodically and harmonically similar.

Heard in succession, the songs project a positive Melanesian ethnic consciousness (Lawson 2012, I0), albeit from a Papua New Guinean perspective. (A form of flag waving can be seen in the song's video; when Faunt sings, "I nogat wanpela ples em i olsem PNG" [There's no place like PNG], he tugs at his T-shirt to draw attention to the PNG flag displayed on its front.) The text of "Melanesia (Paradise)" unironically appropriates exoticist "paradise discourse" (Deckard 20I2); embraces the way the region has become a tourist "pleasure periphery" (Douglas I996) in the refrain, "My Melanesia, Waiting to please ya," as well as the sound of the ukulele and steel drums; and concludes with an exhortation to Melanesians to "appreciate the Melanesian Way":

I'm livin' in paradise

And this land I'll never give away

Taim mi lusim yu na mi go long longwe hap tru

(When I leave you and travel far away)

I nogat wanpela ples em $i$ wankain olsem yu

(There's no other place that's anything like you)

Ol kainkain man na meri rabisim yumi

(All sorts of people put us down)

I nogat wanpela ples em $i$ olsem PNG

(There's no place like PNG)

In the Pacific Ocean, the New Guinea islands

Unique, exotic, God's creation 
Cool misty mountains, valleys and plains

Tropical islands with the monsoon rain

My Melanesia

Waiting to please ya

I'm livin' in paradise

And this land I'll never give away

Long nambis go long maunten planti kainkain samting

(From the beaches to the mountains so much diversity)

Bikman i blesim yumi na yumi mas lukautim

(The Lord has blessed us and we must take care of it)

Holim pasim kastom na ol tumbuna pasin

(Hold on to traditions and ancient ways)

Ol kalsa bilong yumi em i bikpela samting

(Our culture is something profound)

From the valley to the sea let's live in peace and harmony

With so many cultures living in a unity

The last frontier is what many people say

And we must all appreciate the Melanesian Way

Faunt wrote the song "to promote the beauty and cultures. ... No matter how far away I am or how much negative publicity we get, it's still a beautiful place that's waiting to be discovered and appreciated" (pers comm to M Webb, I7 Sept 20I4). In Hausboi's vision of the region, the diversity, both natural and cultural, is considered a gift from God. Here the "to-from" textual mapping device is employed: "from the beaches to the mountains" and "from the valley to the sea." Contrasting placeshighlands and coast-islands-also stand for spaces of cultural diversity. The reference to God, as well as to a "Melanesian Way," points to the ideology of the region's key early postcolonial thinkers, worth considering at this point in order to comprehend the extent to which songwriters' ideas of regionalism align with or vary from this discourse. At least four key themes are clear in the speeches and writings of Bernard Narokobi, Jean-Marie Tjibaou, Epeli Hau'ofa, ${ }^{18}$ and Walter Lini, which can be summarized as follows:

(I) Melanesia is a spiritual space, given by gods or ancestors and held together by God (see Tjibaou 2005, I04; Hau'ofa 2008, 3 I; Narokobi I983, 38-I45); 
(2) Melanesia is a region of extreme diversity where people groups nevertheless share "a basic culture and . . . concepts that explain the meaning of the world" (Tjibaou 2005, I74; see also Hau'ofa 2008, 33; Narokobi I983, 7; and Lini I980, 63);

(3) Melanesia is an Edenic paradise that has been treated as "a wreck to be looted" by colonial-Other interests but that should "more and more be seen as a heritage" (Tjibaou 2005, 64; see also Narokobi I983, 49-63); and

(4) Melanesia contains a shared political identity forged through similar cultural practices, beliefs, colonial histories, and struggles (see Lini's ideas as represented in Premdas I987; see also Narokobi I983, I8-22; Tjibaou 2005, 73-89).

To varying extents, each of these themes is identifiable in the text of "Melanesia (Paradise)." Lawson has reminded us that historically, Melanesia was "attended by certain derogatory assumptions concerning its inhabitants" (20I2, I6). Hausboi point out that more recently the region's reputation has become tarnished-by political and social instability, for example_-singing, "Ol kainkain man na meri rabisim yumi” (Tok Pisin: All sorts of people put us down), and they propose that the real Melanesia is yet to be discovered and appreciated. The easygoing Island-pop feel of the music and the scenic beauty of the islands of Manus Province in the accompanying music video reinforce this message.

Perspectives from Vanuatu

The next pair of songs, "Melanesia" (Jam) (2007) and "Kamzgeta" (2009), were self-recorded and self-produced by musicians who worked collectively under the name "Ni-Van Crew," an abbreviation of the demonym "Ni-Vanuatu." "Crew," now associated with hip-hop culture, is a slang term for a close group who share a common interest. This Melanesian crew is comprised of three pairs of brothers-Vita and Pako ("full Ni-Van"), Matrick and Maddox ("half PNG"), Local Remedy and Jamala ("full Ni-Van")—who grew up together in Western Sāmoa in the early 2000 s as part of the Melanesian diaspora (pers comm, e-mail, Local Remedy to M Webb, I 8 Sept 20II). Musically as well as in terms of identity politics, these songs share an affinity with the work of Sudden Rush—the song "Paradise Lost" mentioned above, but also tracks such as "Paradise Found," "Kanakas United," and "True Hawaiian," from

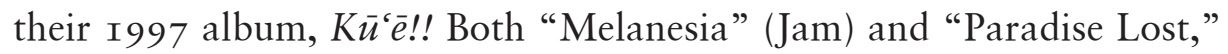


for example, contain lyrical references to blood flowing through veins, and both "Kam 2geta" and "Kanakas United" employ the phrase "birds of a feather."

According to Local Remedy, "Melanesia" (Jam) was created "as a 'challenge' and a patriotic statement": "Growing up in Samoa ... was hard. The cultural differences between Melanesians and Polynesians had an impact on our sense of identity. The song itself was our way of reaffirming and acknowledging our history and culture. It gave us a sense of pride that identified with the modern youth of that time [circa 2005]" (pers comm, e-mail to M Webb, I 8 Sept 20II).

"Melanesia" (Jam) opens with a resounding tympani hit and a pulsating bass riff, closely followed by what sounds like a breaking wave, then a loud, vocal "Yeah" and a keyboard accompaniment figure. The entire song plays over an eight-bar (or repeated four-bar) minor key harmonic cycle, with one chord sounding per bar. Also heard in the musical layers are a diatonic scalar piano loop, a drum kit and handclap pattern, a subbass "drop" (in the seventh bar), and across the eighth bar a conga rhythm cadence often heard in local Shefa Province (Vanuatu) string band songs. Jamala raps the message or "wake-up call" with confidence and urgency in a rapid, staccato-like monotone delivery over the generally agitated accompaniment loop. The unrelenting keyboard part of one chord per bar on the downbeat serves as a kind of portent: musically, there is a strong sense that "Melanesia" is under threat.

Generally speaking, the threat is the focus of the two verses, while the refrain constructs a past-to-future scenario of and for Melanesia in the form of an exhortation to break free from a "primitive" mentalitywhether imposed by others or self-a mindset of suspicion, a "chain of hate." Melanesia must "do things quite properly" and "show some love within," that is, break down barriers of tribalism and envision and enact unity across the entire region. Picking up from the opening refrain, where the threat is identified generally as "hate," the first verse becomes more specific, stating that the threat is one of an internalized inferiority as well as conflict and cultural pride and difference. The panacea is to unite, embrace Melanesian blackness, proudly proclaim a regional identity, and claim a place in the world. The verse ends by asserting that identity is not a surface quality; rather, it is in the blood (compare Tjibaou who explained that a Kanak "is not an individual-he is the core of a relationship; he is the blood running through its veins" [2005, I78]). Verse two concentrates on culture and tradition, as well as the core Vanuatu value of respect. ${ }^{19}$ 
Ultimately, Melanesia is celebrated as a God-blessed region that is united by Christian belief.

Yeah this is a wake up call for all my Melanesian people!

[Refrain]

Melanesia ain't no stopping we can do things quite properly got to take it to the limit then we breakin' out the border takin' over territory like a tropical hurricane from the dirt man out we came delivered out now we ain't the same yeah we break the chain of hate that try to separate us gotta show some love (gotta show some love) within

[Verse I]

I refuse to believe ya

when you tellin' me you can't do a thing 'cause I'm from

Melanesia

too much conflict, too much pride

different cultures separate tribes

you can't really dis us folks better put the black back on the mat man how ya gon' miss us?

we got colonized but it's no excuse for us not to be vocal right?

realize liberty can raise your eyes

raise your voice the world better recognize

it's time for us to stand as one unite the land as one

in the past there was damage done but we can overcome

so stand up as a Melanesian that's my name

you can change my way of life but the blood in my veins flows back to

my heart

[Refrain]

(In) Melanesia ain't no stopping we can do things quite properly ...

[Verse 2]

Yeah we all got dreams though we talk a lot

a struggling mindset to the top

but forget me not 'cause when you go ahead

never leave peeps and your culture at the back of the bus to rot

acknowledge that traditional knowledge is a focal point

you lose the point in life when you forget who you are

where you comin' from where you wanna go keep that in retrospect in Melanesia we show respect and my people my God protects and we still got flaws in the system they can point fingers at my life and belief 
but I know that my land is blessed

to my people in Melanesia stand strong don't get divided

one land one God one people let love unite us ${ }^{20}$

Jamala's rap is densely packed with ideas and projected in fluent English with occasional inclusions from the idiolect of rap, such as "dis" and "peeps." In vocality terms, a mixture of accents is evident, with an African-American rap drawl (RD) employed, for example, in words featuring the /ai/ vowel sound: pride, tribes, colonized, eyes, recognize, and so on. The juxtaposition of this accent with a more typically Melanesian pronunciation of English (ME) can be heard occasionally, in phrases such as "talk a lot" for example, where the accent shifts from /talk/ (ME) to / lot/ $(\mathrm{RD})$. This conveys a sense that the musicians are in the process of "finding a voice," expressing their own collective experience and vision while drawing on the tradition of political or "conscious" United States hip-hop.

"Kam 2geta" is "based on the idea of unity within the Melanesian region, and embracing our diverse cultures," as Local Remedy recalled. He elaborated: "We all had a nationalist and patriotic motive behind our ideas and were fully aware of the conflicts in our region. Our Christian belief and values are also reflected in this song, thus peace, love and brotherhood is an obvious trait." (pers comm, e-mail, Local Remedy to M Webb, I 8 Sept 2OII). ${ }^{21}$ With laid-back tempo, smooth jazz-like backing textures, and use of the Auto-Tune effect, the song draws musical inspiration from contemporary $\mathrm{R} \& \mathrm{~B}$ and rap. It opens with a cymbal wash and shimmering keyboard effect before a heavy drumbeat kicks in under a gliding AutoTuned vocal hook and dreamy backing vocals. In the first verse, a relaxed rap opens by mapping a span between two Melanesian urban centers. The mapping resumes in the third verse, casting eastward to Fiji then filling in additional centers in Solomon Islands and New Caledonia. The rap, as Local Remedy clarified, alludes to episodes of regional unrest, specifically, the most recent military coup in Fiji and the 2006 sacking of Chinatown in Honiara:

\author{
Hem ia nao (That's it) \\ Yumi kam tugeta (Let's unite) \\ [Verse I] \\ From Pom City all the way to Port Vila \\ Everybody get together yumi manki Melanesia (we are Melanesian kids)
}


Ain't no difference with the physical appearance

We all live by the same island traditions

So unite together like birds of a feather

Understand each other

Hold that Melanesian bond make it last forever

Let our songs be the messenger (hem ia nao [that's it then])

[Refrain]

Yumi mas [We have to] come together, stanap [stand strong] together

Melanesian islands yumi [we] unite together

Nogat trouble yumi lavem one another (There'll be no conflict if we love one another)

Love and respect, na hamamas (and happiness/contentment) forever

[Verse 2]

All of Melanesia get together as one

One tropical family under the sun

Let's show the whole world how to have fun

Three different nations speaking only one tone

From the old people all the way to the pikininis (children)

Island groove, Island move, is how we begin

You start moving your feet and get with the beat

Watch the fire burning yeah you can feel the heat

[Refrain]

Yumi mas come together, stanap together . . .

[Verse 3]

Port Moresby to Vila town

Know that we hold it down

Suva city all the way to Honiara hold ya ground

And New Cali they be showin' love

Mi no wari spos yu bakarap (I don't care if you're ruined)

You can't show enough respect

And to the village and the streets

Know that our bond is set in concrete

And we speak what we seek to bring peace

So we make the fresh tunes to cool down the heat ${ }^{22}$

"Kamzgeta" is a rallying call to youth to "hold that Melanesian bond," a variation on the Melanesian Way, which is based on shared appearance, traditions, values (respect is mentioned several times), and pidgin language. The line "Three different nations speaking only one tone" is an allusion to the pidgins spoken in Papua New Guinea, Solomon Islands, 
and Vanuatu, respectively: Tok Pisin, Solomons Pijin, and Bislama. The lyrics code switch between English and Melanesian pidgin, which serves to reinforce to its intended Melanesian audience the song's local and regional message. As with "Melanesia" (Jam), the vocal delivery mixes accents; however, a more Melanesian-sounding approach to enunciation and pronunciation dominates here, particularly in the sung refrain and in the third verse rap, whereas a rap accent sounding more African American is employed in the first and second verses. Ni-Van Crew's songs draw on three of the four key regional discourse themes identified above. Notably, the songs are devoid of paradisiacal references; their message is rather one of collective self-pride, peace, and overcoming division.

\title{
Perspectives from the Margins
}

The final two songs analyzed in this section are by musicians from Melanesia's geographical margins. From Fiji, on the eastern edge, is Jale Mareau's song "Melanesia" (JM), ${ }^{23}$ originally released in 2000 , and from West Papua, in the far west, is the song "Melanesia My Homeland" by a composer-performer whose identity is unknown to us. Mareau's song, as Jennifer Cattermole explained, deals with the prejudice that Solomon Islanders have had to endure concerning their place in Fijian society following the 1987 military coups. Solomon Islanders were brought to Fiji as laborers during the colonial era, and while over the years they intermarried with Fijians, they have not been considered Fijian in Fiji, nor are they considered Solomon Islanders by that country (Cattermole 2006, 9-Ion25). ${ }^{24}$ Mareau asserts that his belonging to the wider region qualifies him for citizenship in the more local place, Fiji. Cattermole has provided the original text and its translation, which deals with devotion to Fiji, how Mareau's parents' generation contributed to building modern Fiji, their rejection by Fiji, and an appeal to God to resolve the problem of displacement (Cattermole 2006, 9-Ion25; see also Cattermole 2009, I67). A brief rhythmically spoken section in English, which is not included in Cattermole's transcriptions, can be heard in the middle of the song:

\author{
Well I'm a Melanesian and I'm proud of that \\ And my family's here to stay \\ We've been here for a really long time \\ And we work hard day to day \\ I'm a Melanesian and I'm proud of that \\ But I hope that soon some day
}


We could all live together forever in peace

In God's way (what d'ya say, what d'ya say?)

This spoken segment shares a remote affinity with the protest-oriented talking-blues tradition of country and folk music. Mareau explains that, musically, his songs are a blend of country, reggae, and vude (this last style is itself a blend of disco, country, and Fijian indigenous musical elements). However, "Melanesia" is also considered a sigidrigi or "sing drink" song, a genre that within Fiji is considered liminally indigenous on the basis of its hybrid musical features; thus it serves as a metaphor for the composers' own ethnic marginalization (see Cattermole 2009 for a discussion of how the genre sigidrigi is understood in Fiji).

The song "Melanesia my homeland" was published on YouTube in $20 \mathrm{I} 2 ;^{25}$ the composer/performer does not appear to be credited. Lyrically, through mapping, which is reinforced with flagging in the accompanying video by way of picture-in-picture editing, the song sets up West Papua's relationship to Melanesia, a regional homeland comprising Island countries that are currently independent (Fiji, Vanuatu, Solomon Islands, and Papua New Guinea) and territories that hope to be independent in the future (West Papua and Kanaky ${ }^{26}$ ):
[Verse I]
Melanesia my homeland
Melanesia my future
We stand united
Our land is so rich
From Fiji to Kanaky
Vanuatu and Solomons
West Papua and PNG

The message of the refrain is straightforward: West Papua is part of Melanesia; hence it is Melanesia's obligation to "free our land" from Indonesian domination and oppression.

\author{
[Refrain] \\ We stand united \\ We call on you Melanesia \\ Come free our land \\ Come save our people \\ West Papua mi laikim yu (Tok Pisin: I love you)
}


West Papua ples mama karim mi (Tok Pisin: place where my mother bore me)

[Refrain, with alternate last line]

West Papua tanah ibu (Bahasa Indonesia: land of my mother)

Snippets of Tok Pisin and Bahasa Indonesia are employed in the predominantly English text, the former suggesting the singer is domiciled in Papua New Guinea, and both languages expressing more intimately how the singer feels about his motherland. Musically, the song's sentimental melody, delivered in a wide vibrato, slowly unfolds over a chugging guitar, keyboard, and programmed drum kit. According to Jeremy Wallach, "Indonesian tastes in Western pop music tend toward two extremes: loud rock music at one end and treacly sentimental love songs at the other" $(2008,30)$. This song's melody and the singer's vocal delivery indicate a strong influence of Indonesian versions of the latter. From 2:20, a variant on the standard reggae keyboard "bubble" rhythm comes to the fore in the sound mix.

Lyrically, each song in this last pair mentions, if only subtly, several of the four themes of the Melanesian postcolonial thinkers. Mareau's song assumes a common Islands identity and a region whose people share belief in God; the West Papua homeland song appeals to common traditions and struggles and makes a fleeting reference to the paradise theme. This last song leads next to a discussion of four songs that express solidarity with West Papuan demands for independence from Indonesia, the fourth of the four factors we identify as driving the new musical Melanesianism.

\section{Self-Determination Politics: West Papuan Independence}

Lawson has noted that, with regard to the issue of West Papuan independence, Melanesianism has its limits, due to conflicting political interests of various states in the region $\left(20 \mathrm{I}_{3}, 2 \mathrm{O}-2 \mathrm{I}\right)$. The issue has received strong support from Vanuatu, for example, but little encouragement from Papua New Guinea. Bypassing official political channels, regardless of their national origin, musicians across Melanesia are becoming increasingly more vocal in their support for West Papua. ${ }^{27}$ Take, as a first example, the 2012 song "Full Freedom" by Australia-based Papua New Guinean musician Airileke. ${ }^{28}$ Built on densely textured log-drum rhythm patterns, as well as sampled indigenous chants and soundscapes, "Full Freedom" opens with a West Papuan voice proclaiming: 
One tribe

Melanesian

From Sorongs [sic] to Samarai

One skin, one tradition, one culture

Full freedom!

Lyrically mapping the island of New Guinea "from Sorong to Samarai" (these being urban centers located at the extreme opposite ends of the island-Sorong on the West Papuan side, Samarai on the Papua New Guinean side), the song claims West Papuans are Melanesians and true wantoks, belonging to "one tribe," sharing "one tradition" and "one culture" (the second of the four postcolonial themes noted above). The reference to "one skin" is an assertion of shared blackness and infers a stark contrast with "Indonesian" "skin." Figure 2, a poster advertising a concert in support of a politically independent West Papua, with Airileke billed as a performer (with other notable musician supporters of a free West Papua including George Telek), reproduces the Sorong to Samarai "united island" map image employed in the "Full Freedom" music video. The colors of West Papua's flag, red and blue, are a prominent visual theme. West Papua's national motto, "One People, One Soul," runs along the bottom of the poster; here, however, it has been extended to apply to Melanesians from across the entire island of New Guinea. The punchy verbal opening of the song, hammered home with rapid-fire drumming, highlights the fundamental incompatibility between Indonesia and West Papua on the grounds of history (indigenous and colonial), geography, ethnicity-race, and tradition-culture. "Full freedom" ends with a group of West Papuan children chanting the Bahasa term "Merdeka" [freedom-independence]!"

The Vanuatu reggae band Masamp Crew entered its song "West Papua" (composed in 2008) in the $20 \mathrm{I} 2$ Pacific Break song competition. The band's name comes from combining "massive" and "amplifier," a boasting reference to the sound gear the band uses to broadcast its political message. The Pacific Break recording of the song features a genre juxtaposition: opening with a fifty-second segment of New Guinea drum, flute, and rattle music, blended with a chord sequence strummed on acoustic guitar and accompanied by electric bass and electronic keyboard-a sort of homage to an imagined West Papuan culture, perhaps. It then launches into the song in a roots-reggae style: ${ }^{29}$

[Verse I]

United we stand to fight for your victory (woi-io yeh yeh)

The mountains we climb, obstacles surrounding 


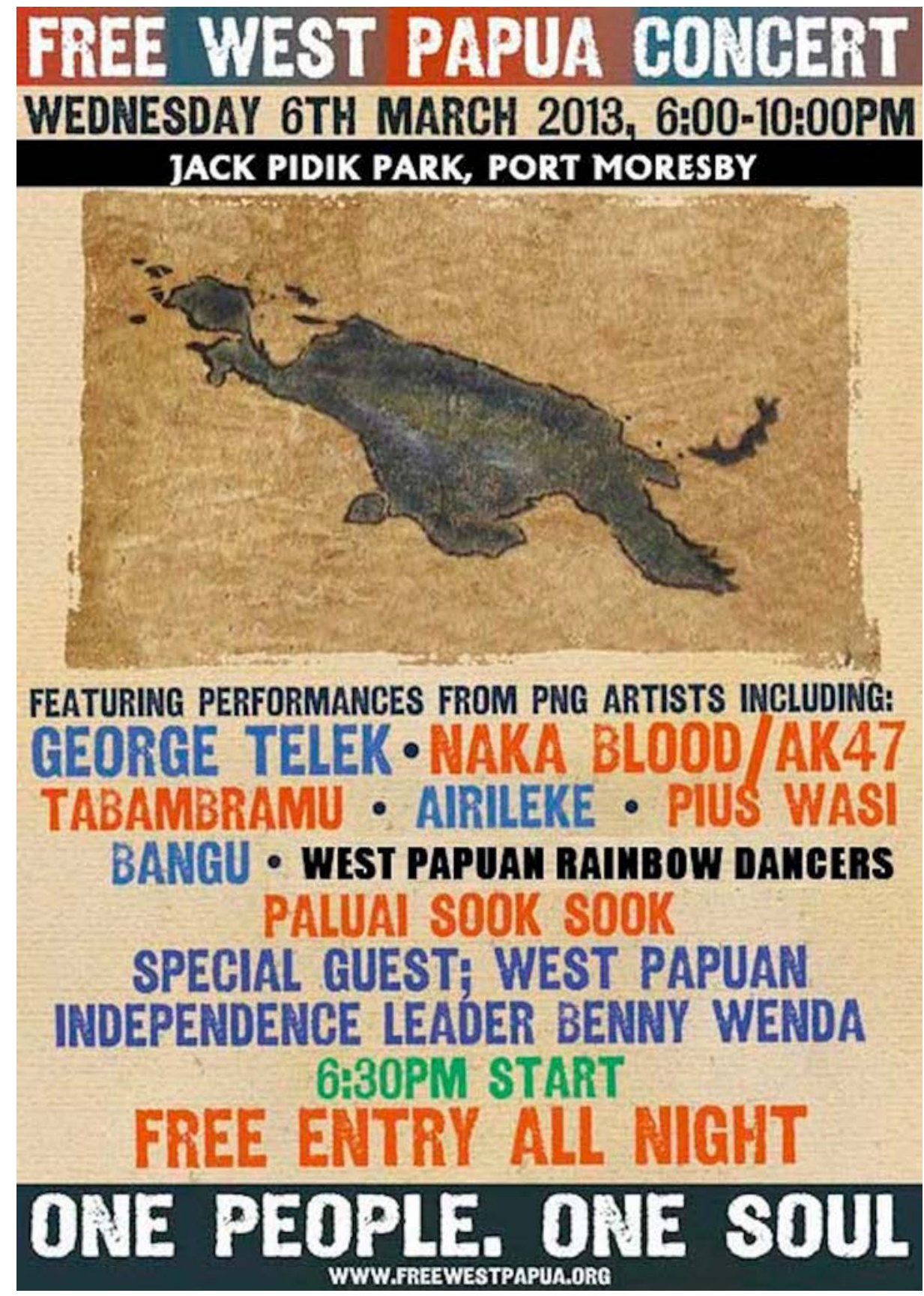

Figure 2 Poster for "Free West Papua" concert held in Port Moresby, Papua New Guinea, 6 March 20I3, employing flagging and mapping devices associated with Melanesian regionalism songs. 
As we never give up reaching your goal

The current is changing focus your direction (woi-io yeh yeh)

So shall your suffering it will be over

[Refrain]

(Now tell me) West Papua

The race is longer but one day you will win

West, West, West Papua

Your days get tougher but Jah will provide

West Papua

How far it will be the days of your journey

West, West, West Papua

The race is longer but one day you will win

[Verse 2]

United we stand get rid of your genocide (woi-io yeh yeh)

We call for Indonesia pull back your borders

Give back the freedom of our black children

So many mountains black man won't you afraid (woi-io yeh yeh)

So shall your suffering it will be over ${ }^{30}$

The text is largely self-explanatory; with mention of Jah (Jehovah), the idea of black transnation comes into view, and the demand that Indonesia pull back its border as well as the references to "black children" and "black man" all serve to emphasize that West Papua is part of Melanesia and West Papuans are Melanesians.

In the reggae anthem "Rise Up," released in 20I I, ni-Vanuatu Gospel pop singer Vanessa Quai invokes the name "Jah" with Christian intent: ${ }^{31}$

[Refrain]

Rise up warriors

Stand up and fight for this nation

Rise up warriors

Never never give up on your hope

Rise up warriors

Stand up and fight for this nation

Rise up warriors

Forever Jah will be by your side

The warrior concept occurs widely in reggae and reggae-related music, some examples being "Reggae Warrior" by Pablo Moses, Ky-Mani Marley's "Warrior," "Warrior" by Chronixx, "Warrior" by Matisyahu, Afro- 
dizia's "Warrior of Jah," and George "Fiji" Veikoso's "Warrior." 32 The Rastafarian is engaged in a spiritual battle against the "system," Babylon. In the context of the West Papuan "fight" for independence, the reggae concept of warrior resonates with the idea that West Papua, a biblical "David" with bows and arrows, is pitted against a "Goliath," Indonesia, with its vast, sophisticated modern weaponry. Although "Rise Up" contains no direct lyrical reference to West Papua, it is obvious from the accompanying video that the song is a call to all Melanesians to be warriors on behalf of the West Papua "nation" and to West Papuans to be patient and resilient in their fight for independence. The video shows dancers performing the West Papuan national dance, the yospan, and the West Papuan flag, known as the Morning Star, is unfolded and paraded for the world to see.

The final song to be discussed is "Let the Morning Star Rise" by Fijian singer Seru Serevi. Recently, Fijians have been voicing their dissatisfaction with Indonesia's incursion into Melanesian politics (Webb-Gannon and Elmslie 20I4). As his inspiration for the reggae song, Serevi cited Fiji's collusion with Indonesia against West Papua, as well as the musical activism of West Papua's Black Brothers in the I980s and I990s (Biumaiono 20I4). The refrain envisions the proud unfurling and raising of the West Papuan flag, which in West Papua is considered an offense and can lead to a prison sentence. In the lyrical buildup to the refrain, Serevi widens the focus to incorporate all Pacific Island regions including one he refers to as Austronesia; by this he might mean indigenous Australia, although he could be referring to the entire region where Austronesian languages are spoken, including Taiwan, Island Southeast Asia, and Austronesian Oceania (Micronesia, Melanesia, and Polynesia).

Come Melanesia (can't you hear them calling)

Come Polynesia (help our brothers now)

Come Micronesia (hear our sisters crying out)

Come Austronesia (and let's help our brothers)

Let the Morning Star rise

Rise Morning Star

Freedom to West Papua

Freedom to our Melanesian brothers

Oh freedom

Freedom now

Free our Melanesian brothers now ${ }^{33}$ 
In a sense, Seru Serevi's song brings Melanesian musical activism full circle, back to Fiji, from which country around the early I990s, as has been noted, Rootstrata released "Brother Kanaki," a song that has become a Melanesian reggae classic. Certainly, West Papua's treatment by the Indonesian military and its mounting political determination have made people across Melanesia more conscious of their wider regional sense of communality. Songs such as these have the emotive capacity to bind Islanders together generally, as well as in support of West Papuan independence.

\section{CONCLUSiON}

In his renowned postcolonial critique of the perduring portrayals of the Pacific Islands constructed and circulated by Europeans since the earliest years of contact, Epeli Hau'ofa declared: "A new sense of the region that is our own creation, based on our perceptions of our realities, is necessary for our survival in the dawning era" $(2008,47)$. Hau'ofa encouraged the valuing of local, not foreign, expertise-of "images, sounds, and movements that speak to us, that speak of us in our place and our times" (White 2008 , xvii). In this article we have demonstrated that images, sounds, and movements are now being used to project a new sense of Melanesian regional belonging, one that marks out a unique place in the world for a linguistically and culturally diverse group of Islanders in the southwestern Pacific. This phenomenon, we proposed, is driven by four factors: diasporic experience as well as a general increase in mobility and global awareness; dissatisfaction with the ruling class; desire to counter negative portrayals of the region abroad; and deep concern over the deprivation of fellow Melanesians' rights to political autonomy. In his recent rap piece "Three Meals," ni-Vanuatu musician Local Remedy enfolds these factors into a compact statement:

Lookin' around all I see is shantytowns

Poverty and hopelessness here all around

I pray to God that we need to find common ground

I pray to God that we need to find common ground

What happened to our forests and our ground minerals

Unemployment's leaving everyone here cynical

Tell them situation here man is getting critical

Economic status over here is getting ridiculed

Corporations taking advantage of our brothers

West Papua is getting dragged right through the gutter 
Gold oil and minerals stolen in abundance

And all these major governments are the ones that fund this

They'll never tell you this in your textbooks

Protest in public and police will give you left hooks

Greed depriving others from living

Basic human rights in our region is missing

And you ask me why the youth fight and steal

All them wanna do is secure their next three meals

And you ask me why the youth fight and steal

All them wanna do is secure their next three meals ${ }^{34}$

The reenvisioning of Melanesianism has not led to a singular view; nevertheless, as we have demonstrated, while employing the concept of wantok-ism it also reiterates key themes of the region's seminal postcolonial thinkers. ${ }^{35} \mathrm{~A}$ significant musical addition to these themes is the elaboration of the idea of "one skin" or blackness as a regional identity distinctive, one that turns the pejorative associations of being labeled the black "nesia" into a feature to celebrate. In complex ways, through musical styles and their associations, the local notions of blackness intersect with ideas of a black transnation.

We have begun to explore the lyrical, musical, and visual devices through which musical Melanesianism is being articulated and projected, including mapping, flagging, dancing, and vocality-devices from the "do-it-yourself kit” for performing regionalism (Foster 2002, II). To recapitulate, consider the opening of the "Three Meals" piece referred to immediately above, in which rapper Local Remedy announces:

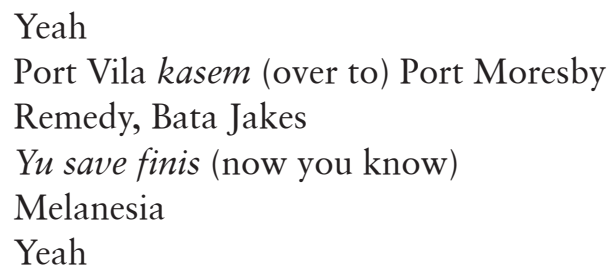

In this abbreviated musical signature, the capital cities of Local Remedy's and producer Bata Jakes's country of origin are mapped, and Melanesia is named, to underscore that the track involves transregional collaboration. Local Remedy intersperses snatches of Bislama and delivers the introduction in a choppy manner, in contrast with the measured drawl of the fluent English rap that immediately follows, in which the accents assumed reveal 
the musicians' familiarity with a range of global hip-hop styles including those from the United States, Grime from the United Kingdom, Urban Pasifika from New Zealand, and reggae-hip-hop fusions from Jamaica. The switches between accents and kinds of diction and declamation are complex in meaning and communicate something about being indigenous, Melanesian, and unique in a globalizing world.

This article has shown that region making is no longer solely in the hands of Melanesia's elites. The new regionalist discourse we have examined and analyzed has bubbled up from the realm of popular culture being created chiefly by a Melanesian "urban grassroots," that is, by those raised in cities and towns, as well as in diasporic contexts, rather than in rural villages. Perhaps, as Subam asserts, music—singing, dancing —in this popular form, is Melanesia's elemental "one-talk."

* $*$

We DEDICATE THIS ARTICLE to the memory of all those who have lost their lives in the struggle for independence and a just peace in the Melanesian Islands and to the political legacy of the Black Brothers. Our thanks to the following musicians for providing us with lyrics (some of which we did not have the space to include) and (or) for clarifying certain points in the lyrics: John Faunt, Ronny Kareni, Masamp Crew, Local Remedy, and Yung Yanny. In the early stage of our research, Local Remedy directed us to particular songs and artists, for which we are grateful. Thank you also to Philippe Saibiri for an extended conversation at the beginning of our research for the article and to the anonymous reviewers and editorial board of The Contemporary Pacific for helpful comments.

\section{Notes}

I This statement appears on the Wantok Musik Foundation website (http:// www.wantokmusik.org/\#! info/cr6ry). Subam (who died in 20II) was a founding member of the PNG ethnic fusion band Sanguma and a music lecturer at the University of Papua New Guinea.

2 Three of the songs we analyze in this article share the title "Melanesia." For clarity we place the following abbreviations after the title in the text: JJY (for Jagarizzar, J-Lee, and Yung Yanny); Jam (for Jamala); and JM (for Jale Mareau).

3 The song can be heard on YouTube as a static video clip: "Melanesia Jagarizzar and Yung Yanny Feat. Jamie Lee - Prod. by B-Rad - 20I I Island Riddims" (6 Jan 20I2), accessed 9 Oct 20I4, https://www.youtube.com/watch ?v=66hXHyouCYw.

4 All song texts appear in the language in which they are sung; except where 
noted, transcriptions and translations (which appear in brackets) are by the authors. John Faunt and Local Remedy kindly checked our transcriptions of songs they composed and saved us from errors, for which we are grateful.

5 The term "local tourist" has two meanings: it is self-deprecating Tok Pisin slang for an idle person, and it can also be a reference to a Papua New Guinean who is visiting in a province or area that is not her or his own.

6 "West Papua" is the name used by the Melanesian populations indigenous to the two provinces of Papua and West Papua for their territory, which has been under Indonesian military occupation since I962-I963.

7 For interesting commentary on this and related ideas, see the discussion in the Reggae \& Hawai'i blog by Rudeboy, especially from paragraph 9: http:// www.hawaiianreggae.org/identity/.

8 See, for example, the music segment on the Melanesian Arts Festival from I3:I7 (and especially around I8:20): "The Pacific Way - Season 9 Episode 9" (22 June 20I4), YouTube video clip, accessed I I Oct 20I4, https://www.youtube .com/watch?v=JOLpnh 5 LQOw.

9 Sanguma also employed this model, over a longer time span, and with it achieved considerable acclaim (see Crowdy 20I 5). The Black Brothers reinvented themselves musically, finally settling on a musical combination of rock, reggae, and sentimental pop. At least one other Papuan rock band, Black Sweet, was inspired by the Black Brothers' musical approach and appears to have enjoyed popularity in the 1980 s.

Io The original recording of "Huembello" can be heard on YouTube: "Huembello (197?) - Black Brothers" (23 Oct 20II), video clip, accessed 3 Oct 20I4, https://www.youtube.com/watch?v=hPGwcelvGHQ.

I I We have been unable to establish the release date of this song. It is likely to have been the late I980s, possibly in response to the news of the assassination of Jean-Marie Tjibaou, which shocked the region.

I2 "Brother Kanaki" can be heard on YouTube, accompanied by a listenercontributed image sequence, which includes a filmed extract of a speech by JeanMarie Tjibaou: "Rootstrata Brother Kanaky" ( 44 July 20I3), video clip, accessed 3 Oct 20I4, https://www.youtube.com/watch?v=5cOEWif $57 \mathrm{qk}$.

I 3 "Paradise Lost" can be heard on YouTube: "Paradise Lost (Sudden Rush)" (I4 March 20I2), video clip, accessed 7 Oct 20I4, https:/www.youtube.com/ watch? $v=w_{k n}$ PLtwFeo.

I4 The notions "Pasifika" and "Pasifikans" are taken up in the next section.

I 5 Early songs from Melanesia with lyrical texts based on mapping and national identity include "Wan Kantri" (1992) by Barike and "Kantri bilong Yumi” (1994) by Rex Band, both of Papua New Guinea. Lyrical mapping continues to feature as a textual device in popular songs in Papua New Guinea. For a PNG local-provincial version, see the 2013 song "Morobe Feeling" by Jokema (the video accompanying it also features flagging in the form of faces painted the 
colors of the provincial flag): "Jokema Morobe Feeling Official Video" (I June 20I3), video clip, accessed 7 Oct 20I4, YouTube, https:/www.youtube.com/ watch?v=EEAqokQNqdI. See also the recent cover version of "My Island Home" by Mau Power from the Torres Strait Islands (part of Australia territorially, yet belonging to Melanesia culturally). Flagging features prominently in the music video, as does mapping in the extended rap: "Mau Power Island Home - Official Music Video" (20 March 20I4), video clip, accessed I6 June 20I 5, YouTube, https://www.youtube.com/watch?v=XXkwDeaQSo8.

I6 John Faunt (the song's composer) checked and made several corrections to our transcription of this text.

I7 Faunt forwarded the link to the written source that inspired the song ( $\mathrm{ABC}$ Catalyst 2003).

I 8 We include Hau'ofa here, although he became significant slightly later than the others and his focus was more transregional.

I9 Throughout Vanuatu emphasis is placed on respect. Bolton noted: "Respect is a centrally important concept throughout the archipelago. ... While the term is used to cover practices concerning gardens, the sea and the bush, it is also used to refer to prescriptions for proper behaviour between people" (I998, np).

20 Local Remedy provided this text transcription.

2I Melanesian regionalist discourse is imbued with Christian-like thinking, which is evident from these two songs. As Tjibaou stated, "we share a certain way of viewing the world with the Bible," and "the word of our people follows the same pattern as the biblical word. And we are not embarrassed to use the Bible" (2005, I 57-I 58; see also Narokobi I980, 9).

22 Local Remedy provided this text transcription.

23 This song can be heard on YouTube: "Melanesia by Jale Mareau" (3 I Dec 20IO), video clip, accessed 8 Oct 20I4, https://www.youtube.com/watch ?v=LLaEIcYT 8 is.

24 In 2008 , a military decree declared that all citizens of Fiji should be called "Fijian," regardless of ethnicity (see, eg, Narsey 20I2).

25 This song can be heard on YouTube: "Melanesia My Home Land" (I3 Oct 20I2), video clip, accessed I3 Oct 20I4, https://www.youtube.com/watch ?v=fEBA6qurrgM.

26 All of the flags of the countries named in the lyrics appear in the insert frame, with the exception of the Kanak flag.

27 As we were completing this article, Solomon Islands R\&B and reggae singer SoulJay launched the song and video "Free West Papua": see "Melanesia for Free West Papua Merdeka Song by Soul Jay Solomon Islands" (25 June 20I 5 ), video clip, accessed 28 July 20I 5, https://www.youtube.com/watch?v=kv9SQap_9z4. Also in 20I 5, Jay P Nalei and Evelyne Meouma (of New Caledonia) released the hip-hop track "West Papua" featuring French-language rapping and a Bislama chorus: see "Melanésia Free West Papua" (I 8 Jan 20I5), video clip, accessed 
28 July 20 I $_{5}$, https://www.youtube.com/watch?t=I 72\&v=-86R9-k9Lz8. Both of these songs contain direct references in their lyrical text to a united Melanesia. Islander musicians outside of Melanesia have also begun to offer musical support for West Papuan independence. For example, in 2015 New Zealander-Samoan Andrew Faleatua composed "In the West," which contains the lines "Come with me let's sail the sea / To the West, to the West Papua / Can you see the broken dreams / The tears of blood raining down / In the West in the West Papua" (pers comm, Faleatua to M Webb, 26 Feb 2015).

28 This song can be heard and viewed on YouTube: "Airileke-Full Freedom" ( I 6 Oct 20I3), video clip, accessed 7 July 20I 5, https://www.youtube.com/ watch?v=Yfj6blGjcXE.

29 The ABC Radio Pacific Break recording of Masamp Crew's "West Papua" can be heard on the Radio Australia website: "Vanuatu's Masamp Crew Sing for West Papua” (27 Sept 20I2), accessed 8 Oct 20I4, http://www.radioaustralia .net.au/pacific/radio/onairhighlights/vanuatus-masamp-crew-sings-for-west -papua/ıо 84IO. A version with accompanying images is on YouTube: "Vanuatu Reggae-Masamp Crew for West Papua” (24 Nov 201 2), video clip, accessed 8 Oct 20I4, https://www.youtube.com/watch?v=PgV6oLnX 5 fg.

30 Masamp Crew provided this text transcription.

3I The song can be found on YouTube with its accompanying video: "Vanessa Quai 'Rise Up' 20I3” (I 5 April 20I3), accessed 8 Oct 20I4, https:// www.youtube.com/watch? $\mathrm{v}=\mathrm{wOI}_{2} \mathrm{aPKObg}_{4}$. The video begins with a recording of the call and response, "West Papua!" "Merdeka!" taken from a political demonstration for West Papuan independence.

32 The warrior "theme" also appears in contemporary Aboriginal and Torres Strait Islander songs, including in band/performer names such as Yung Warriors and Street Warriors. See the 2009 collaboration by the latter group with singer Shannon Noll in a cover version of "Solid Rock," where the warrior concept appears in the rap lyrics: (I3 Oct 2009), accessed I 6 June 20I 5, https://www .youtube.com/watch? $\mathrm{v}=\mathrm{O}_{4} \mathrm{LaPJMWLxo}$.

33 A video clip of the song's launch can be seen on YouTube, with Seru Serevi leading the audience through the lyrics: "Seru Serevi - Rise Morning Star (Free West Papua) 20I4" (I3 March 20I4), accessed 8 Oct 20I4, https://www.youtube .com/watch?v=yJ 5 yHzwMlsY.

34 The "Three Meals" rap, here excerpted, was written and performed by Local Remedy of Vanuatu and produced by Bata Jakes of Papua New Guinea; it can be heard on YouTube: “'Three Meals' (Prod. by Bata Jakes)” (6 April 20I4), video clip, accessed 8 Oct 20I4, https://www.youtube.com/watch?v=iUKglDetquE.

35 As Courtney Handman noted, the "Melanesian Way is starting to be synonymous with the failures of [for example] the contemporary Papua New Guinean nation-state," and “instead of 'Melanesian' leaders, much contemporary political discourse demands that politicians be 'good Christians' first” (201 5, 269). 


\section{References}

ABC Catalyst

2003 Maori Origins. Catalyst, 27 March. http:/www.abc.net.au/catalyst/

Barker, John stories/s8238Io.htm [accessed 8 Oct 20I4]

I992 Christianity in Western Melanesian Ethnography. In History and Tradition in Melanesian Anthropology, edited by James G Carrier, I44-I74. Berkeley: University of California Press.

Biumaiono, Solomoni

20I4 A Song About West Papua. Fiji Times, 9 March. http://www.fijitimes

Bolton, Lissant .com/story.aspx?id=262224 [accessed I 3 June 20I 5]

I998 Praying for the Revival of Kastom: Women and Christianity in the Vanuatu Cultural Centre. Paper presented at the "Women, Christians, Citizens: Being Female in Melanesia Today" conference, Sorrento, Victoria, Australia, November.

Carr, James Revell

20I4 Hawaiian Music in Motion: Mariners, Missionaries, and Minstrels. Urbana-Champaign: University of Illinois Press.

Cattermole, Jennifer

2006 Sere ni Cumu and the Contemporary Construction of Place and Identity in Taveuni, Fiji. In Refereed Papers from the and International Small Islands Cultures Conference, held at the Museum Theatre, Norfolk Island Museum, Kingston, Norfolk Island, 9-I3 February 2006, edited by Henry Johnson, I-I 5 . Sydney: Small Islands Culture Research Initiative, Macquarie University.

2009 Fijian Sigidrigi and the Sonic Representation and Construction of Place. Transforming Cultures 4 (I): I49-I7I.

Charry, Eric

2005 Introduction. In The Beat of My Drum: An Autobiography, Michael Babatunde Olatunji, I-I9. Philadelphia: Temple University Press.

Crowdy, Denis

2015 Hearing the Future: The Music and Magic of Sanguma. Honolulu: University of Hawai'i Press.

Crowe, Peter

I995 Melanesian Music on Compact Disc: Some Significant Issues. Pacific Studies I 8 (3): I47-I 59.

Deckard, Sharae

2012 Paradise Discourse, Imperialism, and Globalization: Exploiting Eden. New York: Routledge. 
Douglas, Ngaire

I996 They Came for Savages: Ioo Years of Tourism in Melanesia. Lismore: Southern Cross University Press.

Foster, Robert

2002 Materializing the Nation: Commodities, Consumption, and Media in Papua New Guinea. Bloomington: Indiana University Press.

Golub, Alex

20I4 Leviathans at the Gold Mine: Creating Indigenous and Corporate Actors in Papua New Guinea. Chapel Hill, NC: Duke University Press.

Handman, Courtney

20I4 Critical Christianity: Translation and Denominational Conflict in Papua New Guinea. The Anthropology of Christianity vol I6. Oakland: University of California Press.

Harrison, Simon

I993 The Commerce of Cultures in Melanesia. Man 28:I39-I 58.

Hau'ofa, Epeli

2008 We Are the Ocean: Selected Works. Honolulu: University of Hawai' $\mathrm{i}$ Press.

Henderson, David

2014 World Music Videos Today. World Literature Today, March. http://www.worldliteraturetoday.org/20I 4/march/world-music -videos-today\#.VCuHB $2 S_{1} Y_{4}$ [accessed I 3 June 20I 5 ]

Knauft, Bruce

I999 From Primitive to Postcolonial in Melanesia and Anthropology. Ann Arbor: University of Michigan Press.

Kornelly, Sharon

2008 Dancing Culture, Culture Dancing: Celebrating Pasifika in Aotearoa/

New Zealand. PhD dissertation, Temple University, Philadelphia.

Lawson, Stephanie

2012 Indigenous Nationalism, "Ethnic Democracy" and the Prospects for a Liberal Constitutional Order in Fiji. Nationalism and Ethnic Politics I 8 (3): 293-3 I 5 .

2013 "Melanesia": The History and Politics of an Idea. Journal of Pacific History 48 (I): I-22.

Lindstrom, Lamont, and Geoffrey White

I990 Island Encounters: Black and White Memories of the Pacific War. Washington DC: Smithsonian Institution Press.

Lini, Walter

I980 Beyond Pandemonium: From the New Hebrides to Vanuatu. Wellington: Asia Pacific Books. 
Lyons, Martyn

I986 The Totem and the Tri-colour: A Short History of New Caledonia since I774. Kensington: New South Wales University Press.

Matsuda, Matt

2012 Pacific Worlds: A History of Seas, Peoples and Cultures. Cambridge: Cambridge University Press.

McGavin, Kirsty

2014 Being "Nesian": Pacific Islander Identity in Australia. The Contemporary Pacific 26:I 26-I 54.

Moore, Clive

2003 New Guinea: Crossing Boundaries and History. Honolulu: University of Hawai'i Press.

Narokobi, Bernard

I983 The Melanesian Way. Port Moresby: Institute of Papua New Guinea Studies.

Narsey, Wadan

2012 Fijians, I-Taukei, Indians and Indo-Fijians: Name Changes by Military Decree. Wadan Narsey on Fiji (blog), I 2 March. https://narseyonfiji .wordpress.com/201 2/03/I 8/fijians-i-taukei-indians-and-indo-fijians -name-changes-by-military-decree/ [accessed I 4 May 20I 5 ]

PIPP, Pacific Institute of Public Policy

20I I Youthquake: Will Melanesian Democracy Be Sunk by Demography? Discussion Paper 17, March. Port Vila: PIPP. http://www.pacificpolicy

Premdas, Ralph .org/wp-content/uploads/20I 2/05/DI7-PiPP.pdf

I987 Melanesian Socialism: Vanuatu's Quest for Self-Definition and Prob-

Smail, Daniel lems of Implementation. Pacific Studies I I (I): I07-I 29.

I999 Imaginary Cartographies: Possession and Identity in Late Medieval Marseilles. Ithaca, NY: Cornell University Press.

Smythe, Julian

2013 The Living Symbol of Song in West Papua: A Soul Force to Be Reckoned With. Indonesia 95:73-9I.

Tjibaou, Jean-Marie

2005 Kanaky. Translated by Helen Fraser and John Trotter. Canberra: Pandanus.

Waddell, Eric

2008 Jean-Marie Tjibaou, Kanak Witness to the World: An Intellectual Biography. Pacific Islands Monograph Series 23. Honolulu: Center for Pacific Islands Studies and University of Hawai'i Press.

Wallach, Jeremy

2008 Modern Noise, Fluid Genres: Popular Music in Indonesia, I997200I. Madison: University of Wisconsin Press. 
Webb, Michael

20I 5 Heart, Spirit and Understanding: Protestant Hymnody as an Agent of Transformation in Melanesia, I840s-I940s. Journal of Pacific History 50 (3): 275-303.

Webb-Gannon, Camellia, and Jim Elmslie

20I4 MSG Headache, West Papuan Heartache? Indonesia's Melanesian Foray. Asia Pacific Journal I2 (47), 24 November. http://www .japanfocus.org/-Camellia-Webb_Gannon/4225

White, Geoffrey

2008 Introduction. In We Are the Ocean: Selected Works, by Epeli Hau'ofa, ix-xx. Honolulu: University of Hawai'i Press.

Woods, Alyssa

2009 Rap Vocality and the Construction of Identity. PhD dissertation, University of Michigan.

\section{Abstract}

This article identifies and explores an emerging tendency among Melanesians to reenvision their region for the present time. It examines a corpus of popular songs and accompanying videos produced over the last decade that promote regional identity, a phenomenon driven by four factors: diasporic experience as well as a general increase in mobility and global awareness; dissatisfaction with the ruling class; desire to counter negative portrayals of the region abroad; and deep concern over the deprivation of fellow Melanesians' rights to political autonomy. The article demonstrates that this reenvisioning of Melanesianism reiterates key themes of the region's seminal postcolonial thinkers, Epeli Hau'ofa, Walter Lini, Bernard Narokobi, and Jean-Marie Tjibaou; at the same time it develops the concept of wantok-ism and elaborates the idea of "one skin" or blackness as distinctive, thus turning the pejorative associations and experiences of being labeled the black "nesia" into a feature to celebrate. Analysis in the article is guided by a framework that considers the lyrical, musical, and visual devices through which musical Melanesianism is being articulated and projected: mapping, flagging, dancing, and vocality—devices from the "do-it-yourself kit" for performing regionalism.

KEYWORDS: Melanesia, regional identity, postcolonialism, music, social media, blackness 